\title{
Petrogenesis of Variscan ultrapotassic plutons, Bohemian Massif: Stable isotope evidence
}

T. MAGNA ${ }^{1}$, V. JANOUŠEK ${ }^{1}$, Y. ERBAN KOCHERGINA ${ }^{1}$, A. ANDRONIKOV ${ }^{1}$, A.S. TABAUD ${ }^{1}$, T. VENNEMANN ${ }^{2}$, J.M. HORA ${ }^{1}$

${ }^{1}$ Czech Geological Survey, Prague, Czech Republic; tomas.magna@geology.cz

${ }^{2}$ Institute of Earth Surface Dynamics, University of Lausanne, Switzerland

In the Moldanubian Zone, Viséan ultrapotassic (UK) plutons occur in a close association with felsic HP-HT granulites [1]. They are characterized by high mg\#, contents of $\mathrm{Cr}, \mathrm{Ni}$, alkali metals, $\mathrm{Th}, \mathrm{U}$ and $\mathrm{Pb}$, paralleled by troughs in $\mathrm{Ti}-\mathrm{Nb}-\mathrm{Ta}$ and $\mathrm{Sr}$ [2]. The UK magmas likely originated from a lithospheric mantle segment strongly overprinted by deeply subducted felsic metaigneous crust [3]. During ascent/emplacement, the primary magmas interacted with the predominantly metasedimentary upper plate.

Stable isotope systems may provide a novel insight into the petrogenesis of UK magmas. Magnesium mostly shows a limited variation in $\delta^{26} \mathrm{Mg}(-0.31$ to $-0.19 \%, \mathrm{n}=10)$, largely centered at the average mantle $(-0.25 \%$; [4]). Disparate $\delta^{26} \mathrm{Mg}$ values in a mafic enclave $(0.01 \%$ ) and a $\mathrm{Cpx}$-cumulate $(-0.64 \%)$ may reflect kinetic re-equilibration. In contrast, oxygen spans a less constrained range from mantle- to crustallike values $\left(\delta^{18} \mathrm{O}=6.4-10.8 \%, \mathrm{n}=36\right)$. Lithium is in all cases lighter $\left(\delta^{7} \mathrm{Li}\right.$ from -2.0 to $+1.9 \%, \mathrm{n}=33$ ) than the average mantle $\left(\delta^{7} \mathrm{Li}=3.5 \%\right.$; [5]) and rather resembles the range reported for the continental crust [5], manifested also by high Li contents. Cpx-cumulates have $\delta^{7} \mathrm{Li}$ as low as $-5.4 \%$, in part possibly due to post-crystallization diffusion [6].

Unlike $\mathrm{Sr}-\mathrm{Nd}-\mathrm{Pb}$ isotope compositions, severely modified by crustal contamination [2], stable isotope systems reflect the increasing affinity from $\mathrm{Mg}$ to $\mathrm{O}$ and $\mathrm{Li}$ to crustal melts, helping to recognize contributions from the depleted mantle, deeply subducted Saxothuringian crust and a relatively shallow Moldanubian contaminant to the Bohemian UK magmatic rocks.

Supported by the Czech Science Foundation (18-24378S).

[1] Janoušek \& Holub (2007) Proc. Geol. Assoc. 118, 75-86. [2] Janoušek et al. (2019) Lithos 342-343, 239-262. [3] Schulmann et al. (2014) Geology 42, 275-278. [4] Teng (2017) Rev Min Geochem 82, 219-287. [5] Tomascak et al. (2016) Advances in Lithium Isotope Geochemistry. Springer. [6] Weyer \& Seitz (2012) Chem. Geol. 294-295, 42-50. 